\title{
PERCEPTION OF SMALL FARMERS IN SERBIA REGARDING THE USE OF ICT AND POSSIBILITIES OF ORGANIC AGRICULTURE
}

\author{
Tatjana Ilić-Kosanović ${ }^{1}$, Brankica Pažun ${ }^{2}$, Zlatko Langović ${ }^{3}$, Srđan Tomić ${ }^{4}$ \\ *Corresponding author E-mail: zlangovic@kg.ac.rs
}

A R T I C L E I N F O
Original Article
Received: 29 November 2019
Accepted: 12 December 2019
doi:10.5937/ekoPolj1904989I
UDC 631.1.017.3:631.147(497.11)

Keywords:

organic agriculture, small farmers, information communication technologies, education, Serbia

JEL:C12, C83, O13, Q10

\begin{abstract}
A B S T R A C T
During the last two decades there is a growing awareness of the importance of introducing organic agricultural production in Serbia due to issues of health, environmental protection and need for more sustainable agriculture. There is a need for education of small farmers on the possibilities of organic production and significance of information technologies for education, production and marketing. This paper aims to examine the perception on the possibilities of organic production and ICT use concerning their level of education. The study has included 143 farmers from Raška district, municipality Kraljevo. The statistical ANOVA analysis has been done by using the software package SPSS18 to explore an impact the education has on the perception of small farmers on the use of information technologies in education, production, and marketing of agricultural products. The results show statistically significant difference in the perception of small farmers on the usage of information technologies regarding their level of education.
\end{abstract}

(C) 2019 EA. All rights reserved.

1 Tatjana Ilić-Kosanović Ph.D., Assistant Professor, University "Union - Nikola Tesla", School of Engineering Management, Vojvode Mišića Boulevard no. 43, 11000 Belgrade, Serbia, Phone: +381 114140 420, e-mail: tatjana.ikosanovic@fim.rs, ORCID ID (https:// orcid.org/0000-0001-9813-7379)

2 Brankica Pažun Ph.D., Associate Professor, University "Union - Nikola Tesla", School of Engineering Management, Vojvode Mišića Boulevard no. 43, 11000 Belgrade, Serbia, Phone: +381 114140 423, e-mail: brankica.pazun@fim.rs, ORCID ID (http://orcid. org/0000-0002-9452-5064)

3 Zlatko Langović Ph.D., Associate Professor, University of Kragujevac, Faculty of Hotel Management and Tourism, Vojvodjanska bb, 36210 Vrnjacka Banja, Serbia, Phone: + 381 36515 0024, E-mail: zlangovic@kg.ac.rs, (https://orcid.org/0000-0002-0248-0453)

4 Srđan Tomić Ph.D., Associate Professor, "University - Union Nikola Tesla”, School of Engineering Management, Vojvode Mišića Boulevard no. 43, 11000 Belgrade, Serbia, Phone: +381 114140 420, E-mail: srdjan.tomic@fim.rs, ORCID ID (https://orcid.org/00000002-6145-6947) 


\section{Introduction}

The need for the better-quality agricultural products is on the rise, for both conventional and organic products. And one of the main questions that worry today's population is: are we eating healthy agricultural products (Tasiopoulou et al., 2007). Thus, the need for organic agricultural products is increasing not only in the developed countries, but in the emerging markets, as well.

During the last two decades, in many countries, there is a growing awareness of the importance of introducing organic agricultural production due to the issues of environmental protection, a need for more sustainable agriculture, population health concerns, etc. Organic production, among others, includes using less or no pesticides and synthetic fertilizers, using bio fertilizers, breeding free range livestock and poultry, decreasing the pollution (Milenković, Tasić, 2013; Nikolova, 2013; Vlahović et al., 2015; Mladenovic et al., 2016; Golijan et al., 2017; Krstić et al., 2017; Yildirim et al., 2018). Organic products are richer in vitamins and minerals, and are of a better quality than the conventional ones (Komorowska, 2014; Barjaktarović et al., 2016; Nikolić et al., 2017). Selling organic agricultural products at the local markets has an impact on economic development of the region and on environmental protection as it saves energy and decreases air pollution levels (Dantsis et al., 2009).

The production of organic goods is rapidly increasing in the 21 st century, thus becoming important economic factor, and the demand in the EU countries grows between 20 and 25 per cent annually and the share of organic agricultural lands increases about 10 per cent annually (Barjaktarović et al., 2016, Branzova, 2017).

Agriculture's contribution to Serbia's GDP constantly remains high. (Pažun et al., 2016a), but still is necessary adjusting economic policy due to prices and competitiveness of domestic agricultural products (Pažun et al., 2016b; Kranjac, Tomić, 2017). Officially, organic production in the Republic of Serbia has begun in the late 1980s and early 1990s (Tomaš-Simin, Glavaš-Trbić, 2016) and it is regulated by the Law on organic production from 2010 (Zakon o organskoj proizvodnji, 2010). Just in last couple years, in Serbia, the organic area increased approximately fourteen times compared to 2008, when began to keep a record of organic production. (Djelic et al., 2019)

Like in other countries in Europe (Kyrylov et al., 2018), especially developed countries, the demand for organic agricultural goods in Serbia is rapidly increasing, nevertheless the domestic organic production is not following the growing demand for the organic agricultural commodities (Ljumović et al., 2015). Overall, Serbian agriculture is in the process of adjusting to the market conditions (Langović Milićević, et al., 2014), there is diverse agriculture production in Serbia, but the share of organic agricultural products is still rather small. The most promising organic agricultural products in Serbia are fruits, namely plums, raspberries, apples, (Milenković, Tasić, 2013).

The possibilities for organic agriculture products' export are almost limitless, as many European countries (Germany, Austria, Sweden, Switzerland, and Denmark) have 
a great demand for organic agricultural products (Gajdić et al., 2018). Other than environmental, climate, and market issues, the most disruptive factors for organic agricultural production are lack of funds (Ljumović et al., 2015) that would cover conversion and other costs, inexperience in products' marketing (Gajdić et al., 2018), and all of that can be applied to the Republic of Serbia.

The other problem is lack of interconnections between small agricultural producers in Serbia, as well as the communication with the processing industry representatives and the market. (Ljumović et al., 2015). Also, lack of government and local government financial aid and doubts about nongovernmental institutions and financial institutions funding plays an important role in deciding against converting into organic agricultural production of the small agricultural producers. Many countries are aware of this problem, and, for example, Turkey from 2005 has developed numerous programs of subsiding the organic agricultural producers in order to increase the economic feasibility of organic agricultural production (Konyali et al., 2018). There is a notion that the younger farmers are more likely to undertake a long and expensive project of converting to organic productions for the reasons of economic prosperity, environmental protection and health issues, so the most programs are aimed at younger population.

On the other hand, information technology is changing the world, therefore agricultural sector. Digital technologies have a strong influence on all aspects of society, therefore can offer valuable solutions to problems and thus provide various opportunities for improving the agricultural sector, both in developed and developing countries. New paradigm regarding high technology development, natural resource protection, is so called precision agriculture, which has been the main challenge for EU agriculture (European Parliament, 2014). The focus is on optimization of agricultural production and profitability.

\section{Materials and methods}

The purpose of this research is to analyse the perceptions of small farmers of Raška district, municipality Kraljevo, villages Lazac and Samaila on the possibilities of organic production and the use of information technologies in education, production, and marketing of agricultural products concerning their level of education.

The villages Samaila and Lazac are situated between towns Kraljevo and Čačak. While Samaila is situated mostly on the flat land, Lazac is in the mostly hilly area. Samaila is spreading on $23.33 \mathrm{~km}^{2}$, and Lazac is spreading on $21.75 \mathrm{~km}^{2}$. (Municipality of Kraljevo, 2017). According to the Municipality of Kraljevo (2017) official documents, Samaila consists of 485 families and 1466 inhabitants and Lazac of 249 families and 695 inhabitants. The population has been decreasing during the last fifty years, according to the Serbia Survey data (Municipality of Kraljevo, 2017). The survey included 143 adult respondents of the abovementioned population that have been fully or partially involved in agricultural production.

The research has been conducted from July $18^{\text {th }}$ until August 10, 2019. The structured questionnaire has been developed via the Google forms platform. Because of the occasional disruptions in Internet connection and the often older population, the data has 
been collected in three methods: in the first approach, two volunteers have been carrying laptops with the access to the forms and the participants filled the forms by themselves; in the second method, the volunteers have been reading the questions or statements and the possible answers to the participants (mostly elderly) and the participants declared the proper ones that the volunteers marked in the proper form; and in the third approach, in the areas, predominantly in Lazac village, with the insufficient access to the Internet, the volunteers have been carrying the paper forms, which the participants filled out and then the volunteers have placed them into the Google form in a exact manner.

In the first part of the survey, the participants have had the opportunity to state their opinions on the organic agriculture and its value, the most suitable products, commitment to organic agriculture and their attitudes toward organic agriculture funding and the possibility of participation in various educational programs. In the second part of the survey, the main research questions have been devised in regard to their perception of the use of information technologies in education, production, and marketing of agricultural products.

For the main research questions, the five-point Likert scale was used to assess the statements (coded as follows: 1 - I disagree completely; 2 - I disagree; 3 - I am neutral; 4 - I agree; 5 - I agree completely). The constructed scale was subjected to the test of reliability and it had strong (0.979) Cronbach's Alpha value, which indicates an excellent level of internal consistency for the scale with the specific sample used for the study.

It is assumed $\left(\mathrm{H}_{1}\right)$ that there is statistically significant difference in the opinion of small farmers in both villages, taking into consideration the level of education, regarding the use of IT in organic production, based on pre-assumption that mostly older or less educated population wants to live in rural areas and wants to work in this field. Several sub hypotheses have been developed further, stating that there is statistically significant difference in the opinion of small farmers on the usage of information technologies in assisting small farmers in:

- $\quad \mathrm{H}_{1 \mathrm{a}}$ : Education on organic production methods;

- $\quad \mathrm{H}_{1 \mathrm{~b}}$ : Projections/analysis of the organic products' market;

- $\quad \mathrm{H}_{1 \mathrm{c}}$ : Managing organic production costs;

- $\quad \mathrm{H}_{1 \mathrm{~d}}$ : Organic products marketing;

- $\quad \mathrm{H}_{1 \mathrm{e}}$ : Inclusion in the appropriate database of certified producers.

$\mathrm{H}_{0}$ states that there is no statistically significant difference in the opinion of farmers taking into consideration the educational level, regarding the benefits of ICT usage in order to assist in education on organic production methods; projections/analysis of the organic products' market; managing organic production costs; organic products marketing; inclusion in the appropriate database of certified producers.

Collected data were tabulated and subjected to statistical analyses by using statistical package SPSS v. 18. 


\section{Results and discussion}

The total sample size has been 143 and $53.8 \%$ of the participants have been from Lazac $(n=77)$ and $46.2 \%(n=66)$ from Samaila. Among the participants, $48.3 \%$ have been female $(\mathrm{n}=69)$, and $21.7 \%$ male $(\mathrm{n}=71)$. The participants have been divided into various age groups, as well as four educational levels, ranging from elementary education to higher education (college or university), as it can be seen at Table 1.

Table 1. The respondents' age and level of education

\begin{tabular}{|l|c|c|l|c|c|c|}
\hline $\begin{array}{c}\text { Respondents } \\
\text { age (years) }\end{array}$ & \multicolumn{2}{|c|}{ Frequency } & \% & \multicolumn{1}{c|}{$\begin{array}{c}\text { Highest educational } \\
\text { level achieved }\end{array}$} & Frequency & $\%$ \\
\hline From 18 to 25 & 15 & 10.5 & Elementary school & 20 & 14.0 \\
\hline From 26 to 35 & 32 & 22.4 & Vocational high school (three years) & 34 & 23.8 \\
\hline From 36 to 45 & 15 & 10.5 & High school & 85 & 59.4 \\
\hline From 46 to 55 & 20 & 14.0 & Higher education & 4 & 2.8 \\
\hline From 56 to 65 & 39 & 27.3 & Total & & \\
\hline Over 65 & 22 & 15.4 & & & \\
\hline Total & 143 & & & & \\
\hline
\end{tabular}

Source: Authors

The most of the respondents have stated that they lived in the households consisting of two to three (37.1\%) and four to five (33.6\%), and as much as $16.1 \%$ of the respondents have stated that they lived in the households of more than five members, which indicates that there is still the institution of extended family that gathers three or more generation. Also, $13.3 \%$ of the respondents have stated that they lived in one member homes (mostly elderly). Among the total number of household members, the most of the families have had two members involved in agriculture (38.5\%), followed by $19.6 \%$ households having one and three members included in the agricultural production respectively. There is the significant number of households that included four (14.7\%) or five $(7.7 \%)$ members included in the agricultural production that also indicates the existence of extended family.

The most of the respondents have stated minimal use of chemical fertilizers or at least the usage with the assistance of agricultural experts or producers' instructions for use which is shown at Table 2. It is necessary to emphasize that $30.8 \%$ of the respondents have stated that they don't use or have never used chemical fertilizers. 
Table 2. The usage of chemical fertilizers

\begin{tabular}{|l|c|c|}
\hline The usage of chemical fertilizers & Frequency & Percent \\
\hline Yes, minimal & 37 & 25.9 \\
\hline According to the producer & 8 & 5.6 \\
\hline According to my personal judgment & 11 & 7.7 \\
\hline According to the agricultural expert & 43 & 30.1 \\
\hline I don't use chemical fertilizers & 30 & 21.0 \\
\hline I have never used chemical fertilizers & 14 & 9.8 \\
\hline Total & 143 & 100.0 \\
\hline
\end{tabular}

Source: Authors

Besides the use of the chemical fertilizers, only $2.8 \%$ of the respondents have stated that they use preventive antibiotics and hormones in livestock breeding, $56.6 \%$ of the respondents have stated that they don't use preventive antibiotics and hormones and $43.4 \%$ have stated that they use only antibiotics if prescribed by the veterinaries.

The most of the respondents $(42.7 \%)$ have stated that organic agriculture is difficult to implement in terms of effort and finance, and as much as $21 \%$ of the respondents agreed that organic production is "fashionable", $13.3 \%$ have stated that organic production is an excellent idea, but not implementable in Serbia, 8.4\% have stated that organic agriculture is an excellent idea, but for the younger generations of the producers, and $14.7 \%$ agreed that organic production is necessary for the ecological future of the country.

As much as $98.6 \%$ of the respondents considered financial issues as the main reason for not involving in organic agriculture and $71.3 \%$ have emphasised the long period for the soil conversion. Also, the concerns have been raised in the market maturity, and there is distrust in the institutions present. From the total sample, $63.6 \%$ of respondents have stated that they would consider involvement in organic agriculture, and $65.7 \%$ have stated that they would start organic production under the assistance of state funds, $51.7 \%$ under the assistance of EU funding programs, and $44.8 \%$ under the assistance of non-governmental institutions' funding programs.

What is very interesting is that $28 \%$ of the respondents have stated that they collect herbs and wild berries. The respondents mostly recognized fruits (plums, apricots, pears, apples, blackberries, blueberries, strawberries, raspberries), garden vegetables (cucumbers, onions, tomatoes, carrots, potatoes, arugula, spinach, broccoli, radishes, squash, zucchini), and aromatic herbs (basil, oregano) as the most suitable corps for agricultural production.

Regarding the possibilities of inclusion in educational programs on the possibilities of organic production, as much as $37.8 \%$ of the respondents would be a part of a free educational program delivered at the premises of the local community centre or school, $18.2 \%$ would attend a free educational program regardless the location, $2.1 \%$ would attend a free educational program in the city of Kraljevo, 9.1\% would attend an internet based free education, and only $2.1 \%$ of the respondents would pay for an educational program on organic production. 
As depicted in Table 3, a majority of the farmers, $23.8 \%$, agreed, and $28.7 \%$ of the respondents strongly agreed that ICT usage can be a useful source due to getting knowledge on organic production methods. The very similar situation is with benefits regarding projections and analysis of the organic products' market, where majority completely agreed about issue, and neutral respondents were in percent of 27.3. Farmers' opinion about the last two questions differ in some way, that is there is no strong agreement about IT benefits in marketing process as well as in inclusion in the appropriate database of certified producers.

As it can be noticed in table, despite all the associated benefits, $23.1 \%$ to $27.3 \%$ of farmers remained undecided on the effectiveness of ICT as the source of agricultural prosperity. Further, only a small segment of respondents did not agree with the usefulness of ICT tools. Possible reason could be inappropriate network infrastructure older habitants, or the lack of education. However, overall, it can be seen that technology has provided multi-dimensional benefits to the small farmers and it helps in all activities, interaction, accessibility, and quick exchange of data.

Table 3. Perceptions of farmers towards ICT usage

\begin{tabular}{|l|c|c|c|c|c|c|c|c|c|c|}
\hline \multirow{2}{*}{ Statement } & \multicolumn{2}{|c|}{1} & \multicolumn{2}{|c|}{2} & \multicolumn{2}{|c|}{3} & \multicolumn{2}{|c|}{4} & \multicolumn{2}{|c|}{5} \\
\cline { 2 - 10 } & $\mathrm{N}$ & $\%$ & $\mathrm{~N}$ & $\%$ & $\mathrm{~N}$ & $\%$ & $\mathrm{~N}$ & $\%$ & $\mathrm{~N}$ & $\%$ \\
\hline $\begin{array}{l}\text { The usage of information techno- } \\
\text { logies can assist small agricultural } \\
\text { producers in: Education on organic } \\
\text { production methods }\end{array}$ & 15 & 10.5 & 19 & 13.3 & 34 & 23.8 & 34 & 23.8 & 41 & 28.7 \\
\hline $\begin{array}{l}\text { The usage of information techno- } \\
\text { logies can assist small agricultural } \\
\text { producers in: Projections/analysis } \\
\text { of the organic products' market }\end{array}$ & 14 & 9.8 & 15 & 10.5 & 39 & 27.3 & 35 & 24.5 & 40 & 28 \\
\hline $\begin{array}{l}\text { The usage of information techno- } \\
\text { logies can assist small agricultural } \\
\text { producers in: Managing organic } \\
\text { production costs }\end{array}$ & 15 & 10.5 & 14 & 9.8 & 38 & 26.6 & 38 & 26.6 & 38 & 26.6 \\
\hline $\begin{array}{l}\text { The usage of information techno- } \\
\text { logies can assist small agricultural } \\
\text { producers in: Organic products } \\
\text { marketing }\end{array}$ & 16 & 11.2 & 14 & 9.8 & 36 & 25.2 & 41 & 28.7 & 36 & 25.2 \\
\hline $\begin{array}{l}\text { The usage of information techno- } \\
\text { logies can assist small agricultu- } \\
\text { ral producers in: Inclusion in the } \\
\text { appropriate database of certified } \\
\text { producers }\end{array}$ & 16 & 11.2 & 19 & 13.3 & 33 & 23.1 & 42 & 29.4 & 33 & 23.1 \\
\hline
\end{tabular}

1 - I disagree completely; 2 - I disagree; 3 - I am neutral; 4 - I agree; 5 - I agree completely; $\%$ - percentage; $\mathrm{N}$ - number of respondents. 
Before beginning One way ANOVA, the Levene's test for Equality of Variances has been carried in order to verify the assumption of equality of variance and it has shown that the assumption of equality of variance has not been violated for all research questions as Sig. values are above .05. The results are presented at Table 4.

Table 4. Test of Homogeneity of Variances

\begin{tabular}{|l|c|c|c|c|}
\hline & Levene Statistic & df1 & df2 & Sig. \\
\hline Education on organic production methods & 1.451 & 3 & 139 & .231 \\
\hline $\begin{array}{l}\text { Projections/analysis of the organic products' } \\
\text { market }\end{array}$ & 1.967 & 3 & 139 & .122 \\
\hline Managing organic production costs & 1.854 & 3 & 139 & .140 \\
\hline Organic products marketing & 1.670 & 3 & 139 & .176 \\
\hline $\begin{array}{l}\text { Inclusion in the appropriate database of certified } \\
\text { producers }\end{array}$ & .473 & 3 & 139 & .702 \\
\hline
\end{tabular}

Source: Authors

One way ANOVA has been applied to formally test the hypotheses and to explore an impact the education has on the perceptions of small farmers on the use of information technologies in education, production and marketing of organic agricultural products. Significance level $(\alpha)$ has been set as .05. The results are presented at Table 5 .

Table 5. One Way ANOVA

\begin{tabular}{|l|l|c|c|c|c|c|}
\hline \multicolumn{2}{|c|}{} & $\begin{array}{c}\text { Sum of } \\
\text { Squares }\end{array}$ & df & $\begin{array}{c}\text { Mean } \\
\text { Square }\end{array}$ & F & Sig. \\
\hline \multirow{2}{*}{$\begin{array}{l}\text { Education on organic pro- } \\
\text { duction methods }\end{array}$} & $\begin{array}{l}\text { Between } \\
\text { Groups }\end{array}$ & 56.891 & 3 & 18.964 & 13.968 & .000 \\
\cline { 2 - 7 } & Within Groups & 188.718 & 139 & 1.358 & & \\
\cline { 2 - 7 } & Total & 245.608 & 142 & & & \\
\hline \multirow{3}{*}{$\begin{array}{l}\text { Projections/analysis of the } \\
\text { organic products' market }\end{array}$} & $\begin{array}{l}\text { Between } \\
\text { Groups }\end{array}$ & 53.039 & 3 & 17.680 & 13.907 & .000 \\
\cline { 2 - 7 } & Within Groups & 176.709 & 139 & 1.271 & & \\
\cline { 2 - 7 } & Total & 229.748 & 142 & & & \\
\hline \multirow{3}{*}{$\begin{array}{l}\text { Managing organic produc- } \\
\text { tion costs }\end{array}$} & $\begin{array}{l}\text { Between } \\
\text { Groups }\end{array}$ & 51.299 & 3 & 17.100 & 13.321 & .000 \\
\cline { 2 - 7 } & Within Groups & 178.435 & 139 & 1.284 & & \\
\cline { 2 - 7 } & Total & 229.734 & 142 & & & \\
\hline \multirow{2}{*}{$\begin{array}{l}\text { Organic products marketing } \\
\text { Groups }\end{array}$} & $\begin{array}{l}\text { Between } \\
\text { Githin Groups }\end{array}$ & 167.635 & 3 & 21.212 & 17.553 & .000 \\
\cline { 2 - 7 } & Total & 231.608 & 142 & 1.208 & & \\
\hline $\begin{array}{l}\text { Inclusion in the appropriate } \\
\text { database of certified produc- } \\
\text { ers }\end{array}$ & $\begin{array}{l}\text { Between } \\
\text { Groups }\end{array}$ & 60.374 & 3 & 20.125 & 16.085 & .000 \\
\hline & Within Groups & 173.906 & 139 & 1.251 & & \\
\hline & Total & 234.280 & 142 & & & \\
\hline
\end{tabular}

Source: Authors 
The results are highly significant as $\mathrm{p}$ value is less than .001 . It is shown that there is statistically significant difference in the perceptions of small farmers on the usage of information technologies regarding their level of education on all research questions. The similar results were conducted in research by Aldosari et al. (2017) where it is shown highly significant relationship between the education of the respondents and the application of radio as information source, but level of education of the respondents had no significant relationship with the application information received through TV. Despite small opposite results, that has been explained as that educational level gives the ability to perceive, interpret and respond to new information much faster than others with lack of education. The study done by Das (2014) has found that farmers mostly rely on ICTs sources for accessing production-related information.

Even though the conducted analysis has shown a statistically significant result, it has still been necessary to examine the effect size through calculating eta squared. The results show, according to Cohen (1988), the large effect size, ranging from .29 for statement 3 to .38 for statement 4 (the statements from the table 3 ).

Post hoc comparisons using Tukey test has indicated that regarding the statement 1, there is a statistically significant difference between the participants with elementary education and three-year high school $\left(\mathrm{MD}=-.976^{*}\right.$, Std. Err. $\left.=.328, \mathrm{p}=.018\right)$ and the participants with elementary education and three-year high school (MD = -.753*, Std. Err. $=.236, \mathrm{p}=.000$ ). In terms of statement 2 , there is statistically significant difference between the participants with elementary education and high school education $(\mathrm{MD}=$ $-.1 .615^{*}$, Std. Err. $\left.=.280, \mathrm{p}=.000\right)$ in addition to three-year high school education and high school $\left(\mathrm{MD}=-.818^{*}\right.$, Std. Err. $\left.=.229, \mathrm{p}=.003\right)$. In regard statement 3 , there is statistically significant difference between the participants with elementary education and high school $(\mathrm{MD}=-1.579 *$, Std. Err. $=.282, \mathrm{p}=.000)$, elementary school and three-year high school $\left(\mathrm{MD}=-.856^{*}\right.$, Std. Err. $\left.=.319, \mathrm{p}=.041\right)$ along with high school and higher education $\left(\mathrm{MD}=-1.679^{*}, \mathrm{Std}\right.$. Err. $\left.=.580, \mathrm{p}=.022\right)$.

Concerning statement 4 there is statistically significant difference between the participants with elementary education and three-year high education (MD = -.968*, Std. Err. $=.310, \mathrm{p}=.012)$, elementary education and high school $\left(\mathrm{MD}=-1.815^{*}\right.$, Std. Err. $=.273, \mathrm{p}=.000)$, three-year high school and high school education $(\mathrm{MD}=-.847 *$, Std. Err. $=.223, \mathrm{p}=.001)$, high school education and higher education $(\mathrm{MD}=-1.465 *$, Std. Err. $=.562, \mathrm{p}=.050)$. Regarding statement 5 , there is statistically significant difference between the participants with elementary education and three-year high school $(\mathrm{MD}=-.859 *$, Std. Err. $=.315, \mathrm{p}=.036)$, elementary education and high school $(\mathrm{MD}=-1.682 *$, Std. Err. $=.278, \mathrm{p}=.000)$, three-year high school and high school education $\left(\mathrm{MD}=-.824^{*}\right.$, Std. Err. $\left.=.227, \mathrm{p}=.002\right)$, as well as high school education and higher education $(\mathrm{MD}=-1.882 *$, Std. Err. $=.572, \mathrm{p}=.007)$. 


\section{Conclusion}

Agriculture is the most important part of Serbia's economy and it facilitates development of rural areas. This research has tried to point out that even in undeveloped rural communities in Serbia, there is an awareness of the importance of using ICT. Presumption of this research has been that younger generations are more educated and that the connection between educational level and the perception of using ICT and organic production is an important insight.

We can conclude that there is statistically significant difference in the perception of small farmers on the usage of information technologies regarding their level of education on all research questions. This confirms that the hypothesis (with sub hypotheses), according to which the education of the small farmers affects their opinions on the use of information technologies in education, production, and marketing of organic agricultural products is confirmed. The results show that the main difference in perception exists between the farmers with elementary education and the farmers with further education (high school or higher education). Therefore, various funding programs for organic production can be developed for more educated population and the less educated population can benefit from educational programs on the organic production and the use of ICT.

Like the most studies, this research study has limitations too. The sample is small and additional and extensive research is needed in order to further explore the perception of small agriculture producers in Serbia in regard to the possibilities of organic production and the use of information technology. This research could include more villages in the Raška district or the other districts, as well as different forms of information communication technology, due to generating a platform not only for resolving some of mentioned challenges, but also for accelerating the efforts to achieve the Sustainable Development Goal (SDGs) by 2030.

\section{Acknowledgements}

The authors would like to thank to Milica Seočanac and Jovana Novaković for their kind assistance in collection of data.

\section{Conflict of interest}

The authors declare no conflict of interest.

\section{References}

1. Aldosari, F., Al Shunaifi, M.S., Ullah, M.A., Muddassir, M., Noor, M.A. (2017). Farmers' perceptions regarding the use of Information and Communication Technology (ICT) in Khyber Pakhtunkhwa, Northern Pakistan. Journal of the Saudi Society of Agricultural Sciences, 18(2), 211-217 (http://dx.doi. org/10.1016/j.jssas.2017.05.004) 
2. Barjaktarović, M., Kuzman, B., \& Žarković, S. (2016). Family Holdings Profitability in the Organic Food Production in the Republic of Serbia. Economics of Agriculture, 1309-1322. doi:10.5937/ekoPolj1604309B

3. Branzova, P. (2017). Organic Production in the Europian Union and Bulgaria Main Crop. Trakia Journal of Sciences, 15 (Supp1), 51-55. (https://doi.org/10.15547/ tjs.2017.s.01.009)

4. Cohen, J. (1988). Statistical power analysis for the behavioral sciences (2nd ed.). Hillsdale, NJ. Erlbaum.

5. Golijan, J., Živanović, L., \& Kolarić, L. (2017). Organic Production of Industrial Crops in Serbia. Field \& Vegetable Crops Research/ Ratarstvo i Povrtarstvo, 54(2), 68-72. (https://doi.org/10.5937/ratpov54-13251)

6. Dantsis, T., Loumou, A., \& Giourga, C. (2009). Organic Agriculture's Approach towards Sustainability; Its Relationship with the Agro-Industrial Complex, A Case Study in Central Macedonia, Greece. Journal of Agricultural \& Environmental Ethics, 22(3), 197-216. (https://doi.org/10.1007/s10806-008-9139-0)

7. Das, B. (2014). ICTs Adoption for Accessing Agricultural Information: Evidence from Indian Agriculture. Agricultural Economics Research Review. 27(2). 199-208. DOI: 10.5958/09740279.2014.00024.X

8. Djelic, A.T., Neskovic, S., Ketin, S., Lutovac, M., Popovic, Z., Mirkovic, M. \& Secerov, P. (2019). Economic and Environmental Context of Organic Agriculture and Farms in Serbia - Case Study. Fresenius Environmental Bulletin, 28(1). 87-92. Retrieved from: https://www. prt-parlar.de/download_feb_2019/

9. Gajdić, D., Petljak, K., \& Mesić, Ž. (2018). An Exploration of Distribution Channels: Challenges and Opportunities for Organic Food Producers in Croatia. Economics of Agriculture, 65(4), 1461-1482. (https://doi.org/10.5937/ekoPolj1804461G)

10.Golijan, J., Popović, A., Dimitrijević, B., Kolarić, L., \& Živanović, L. (2017). The Status of the Forage Organic Production in the Republic of Serbia. Agriculture \& Forestry/ Poljoprivreda i Sumarstvo, 63(3), 177-187. (https://doi. org/10.17707/AgricultForest.63.3.18)

11.European Parliament (2014). Precision Agriculture: An Opportunity for EU farmers - Potential Support with CAP 2014-2020. Brussels

12.Komorowska, D. (2014). Development of Organic Production and Organic Food Market in Europe. Acta Scientiarum Polonorum. Oeconomia, 13(4). 91-101. Retrieved from: http://search.ebscohost.com/login.aspx?direct=true $\& \mathrm{db}=\mathrm{bsu}$ $\& \mathrm{AN}=100723530 \&$ site $=$ ehost-live

13.Konyali, S., Başaran, B., \& Oraman, Y. (2018). Support Policies for Organic Farming in Turkey. New Knowledge Journal of Science / Novo Znanie, 7(2), 55-62. Retrieved from: http://search.ebscohost.com/login.aspx?direct=true $\& d b=b s u$ \&AN $=132203903 \&$ site $=$ ehost-live 
14.Skupština grada Kraljeva. (2017). Osnovne karakteristike. Retrieved from: www. kraljevo.rs/wp-content/uploads/2017/11/01.Osnovne-karakteristike.pdf [in English: Kraljevo Assembly. (2017). Basic information]

15.Kranjac, M., \& Tomić, S. (2017). Clustering in Vojvodina (Serbia). Serbian Journal of Engineering Management, 2(2), 14-19. doi:10.5937/SJEM1702014K

16.Krstić, B., Petrović, J., Stanišić, T., \& Kahrović, E. (2017). Analysis of the Organic Agriculture Level of Development in the European Union Countries. Economics of Agriculture, 64(3), 957-971. https://doi.org/10.5937/ekoPolj1703957K

17.Kyrylov, Y., Thompson, S. R., Hranovska, V., \& Krykunova, V. (2018). The World Trends of Organic Production and Consumption. Management Theory \& Studies for Rural Business \& Infrastructure Development, 40(4), 514-530. (https://doi. org/10.15544/mts.2018.46)

18.Langović Milićević, A., Tomašević, V. \& Isaković, S. (2014). The Importance of Successful Project Team Communication in Agribusiness, Economics of Agriculture, 61(2), 367-379. COBISS.SR-ID 27671. doi:10.5937/ekoPolj1402367M

19.Ljumović, I., Viduka, B., \& Cvijanović, J.M. (2015). Access to finance for organic producers in Serbia: demand side. Economics of Agriculture, [S.1.], 62(4), 989-1002, ISSN 2334-8453. doi:10.5937/ekoPolj1504989L

20.Milenković, S., \& Tasić, J. (2013). Organska Hrana Kao Perspektivni Proizvod Srbije. Economic Themes, 51(2), 411-424. Retrieved from: http:// search.ebscohost.com/login.aspx?direct=true \&db=bsu\&AN=93425446\&site=ehost-live) [in English: Milenković, S., \& Tasić, J. (2013). Organic food as perspective product of Serbia. Economic Themes, 51(2), 411-424]

21.Mladenovic, J., Pavlovic, N., Ugrinovic, M., Pavlovic, R., \& Zdravkovic, J. (2016). Analysis and Forecasting of Profit by Using Simulation Models for Growing Pea in Conventional and Organic Plant Production in Serbia. Economics of Agriculture/ Ekonomika Poljoprivrede, 63(3), 987-995. doi:10.5937/ekoPolj1603987M

22.Nikolić, S. R., Vuković, P., \& Grujić, B. (2017). Measures to Support the Development of Organic Farming in the EU and Serbia. Economics of Agriculture/ Ekonomika Poljoprivrede, 64(1), 323-337. https:/doi.org/ 10.5937/ekoPolj1701323R

23.Nikolova, M. (2013). Challenges to Organic Agriculture in Bulgaria. Economic Themes, 51(1), 191-207. Retrieved from: http://search.ebscohost .com/login.aspx?direct $=$ true $\& \mathrm{db}=\mathrm{bsu} \& \mathrm{AN}=88917638 \&$ site=ehost-live)

24.Republika Srbija. (2010). Zakon o organskoj proizvodnji. ("Sl. glasnik RS", br. 30/2010 i 17/2019 - dr. zakon)

25. Pažun, B., Langović, Z., \& Langović Milićević, A. (2016a). Econometric Analysis of Exchange Rate in Serbia and its Influence on Agricultural Sector, Ekonomika poljoprivrede - Economics of Agriculture, Institute of Agricultural Economics, Belgrade, Serbia, vol. 63(1), 47-60. (doi:10.5937/ekoPolj1601047P) 
26.Pažun, B., Langović, Z. \& Langović Milićević, A. (2016b). Equilibrium Real Exchange Rate Assessment of the Serbian Dinar: The MB approach. Journal for Economic Forecasting, Institute for Economic Forecasting, 19(1), 76-87. Retrieved from: http://www.ipe.ro/rjef/rjef1_16/rjef1_2016p76-87.pdf

27.Tasiopoulou, S., Chiodini, A.M., Vellere, F. \& Visentin, S. (2007). Results of the monitoring program of pesticide residues in organic food of plant origin in Lombardy (Italy). Journal of Environmental Science \& Health, Part B -Pesticides, Food Contaminants, \& Agricultural Wastes, 42(7), 835-841. doi: 10.1080/03601230701555054

28.Tomaš-Simin, M., \& Glavaš-Trbić, D. (2016). Historical Development of Organic Production. Economics of Agriculture/ Ekonomika Poljoprivrede, 63(3), 10831099. (https://doi.org/10.5937/ekoPolj1603083T)

29.Vlahović, B., Puškarić, A., \& Šojić, S. (2015). Research into Agricultural Producers' Motives for Engaging in Organic Production in the Republic of Serbia. Economic Insights - Trends \& Challenges, 67(2), 31-39. Retrieved from: http://search.ebscohost. com/login.aspx?direct $=$ true $\& \mathrm{db}=$ bsu\&AN=110030112\&site=ehost-live

30.Yildirim, P., Ercan, E., \& Türker, G. (2018). Organic Aquaculture Production in Turkey: A Brief Review. New Knowledge Journal of Sciencel Novo Znanie, 7(2), 137-140. Retrieved from: http://search.ebscohost.com/login.aspx? direct $=$ true $\& d b=$ bsu\&AN=132203913\&site=ehost-live 
